\title{
Intra or Intercytoplasmic Lumina Present
}

National Cancer Institute

\section{Source}

National Cancer Institute. Intra or Intercytoplasmic Lumina Present. NCI Thesaurus. Code C157721.

A morphologic finding where the malignant cell has intra or intercytoplasmic lumina thereby imparting a cribriform or sieve-like architecture. 